\title{
Notes on the vocalizations of Black-capped Babbler (Pellorneum capistratum)
}

Peter Boesman

In the following we briefly analyze and compare voice of the different races of Black-capped Babbler (Pellorneum capistratum). We also try to quantify the extent of any vocal differences using the criteria proposed by Tobias et al. (2010), as a support for taxonomic review. We have made use of sound recordings available on-line from Xeno Canto (XC).

Song of all races is a short phrase of one or just a few whistles, given at intervals. There are seemingly slight differences among races:

nigrocapitatum: whistles are typically either downslurred or upslurred, and in most recordings song phrase is just a single whistle, occasionally two or three (valid over entire range from Thailand, over Peninsular Malaysia to Sumatra).

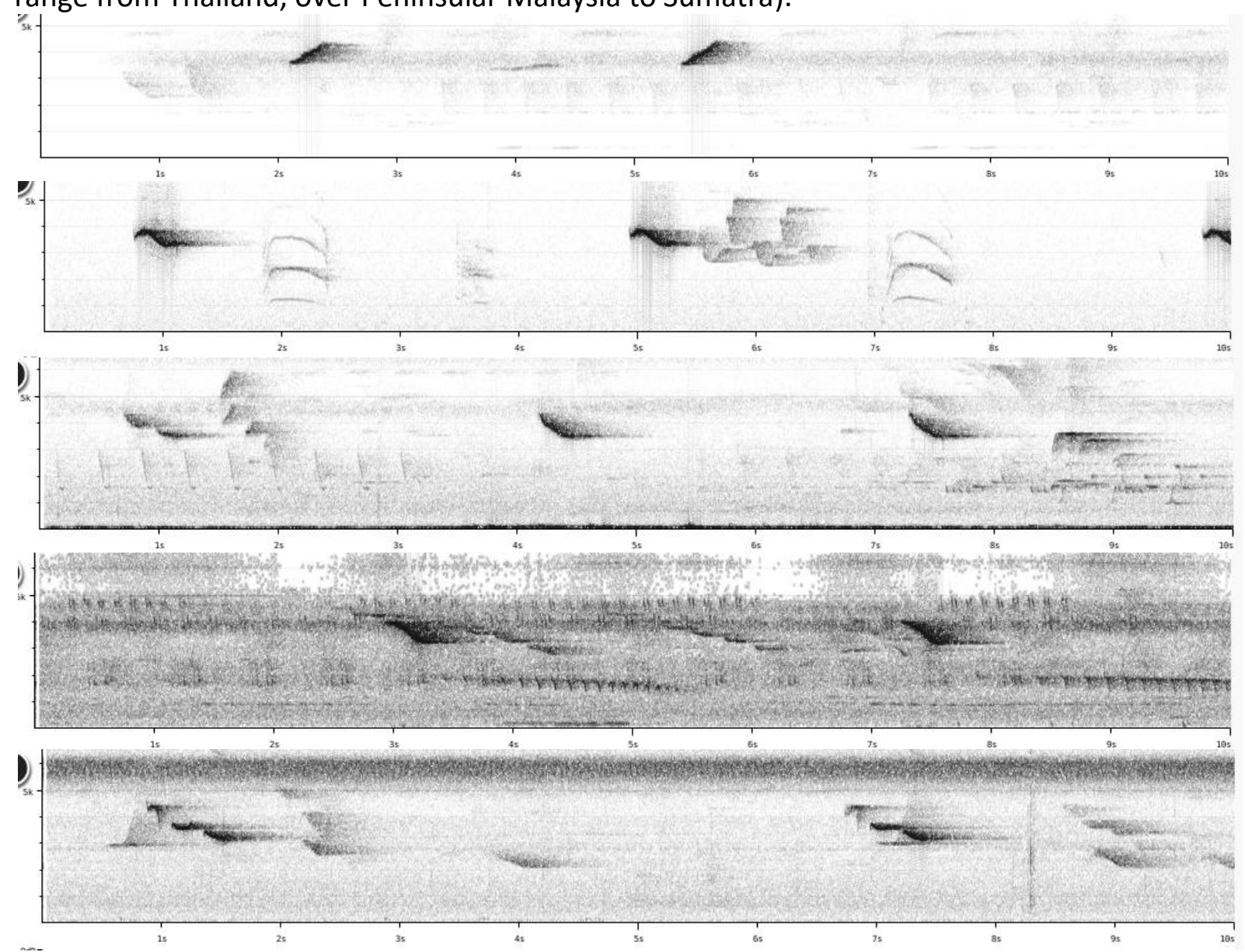




\section{HANDBOOK OF THE \\ Erof \\ Alve}

\section{ORNITHOLOGICAL NOTES}

morelli/capistratoides (Borneo): song is either a single underslurred whistle, or more commonly two or three whistles (which are also rather underslurred)

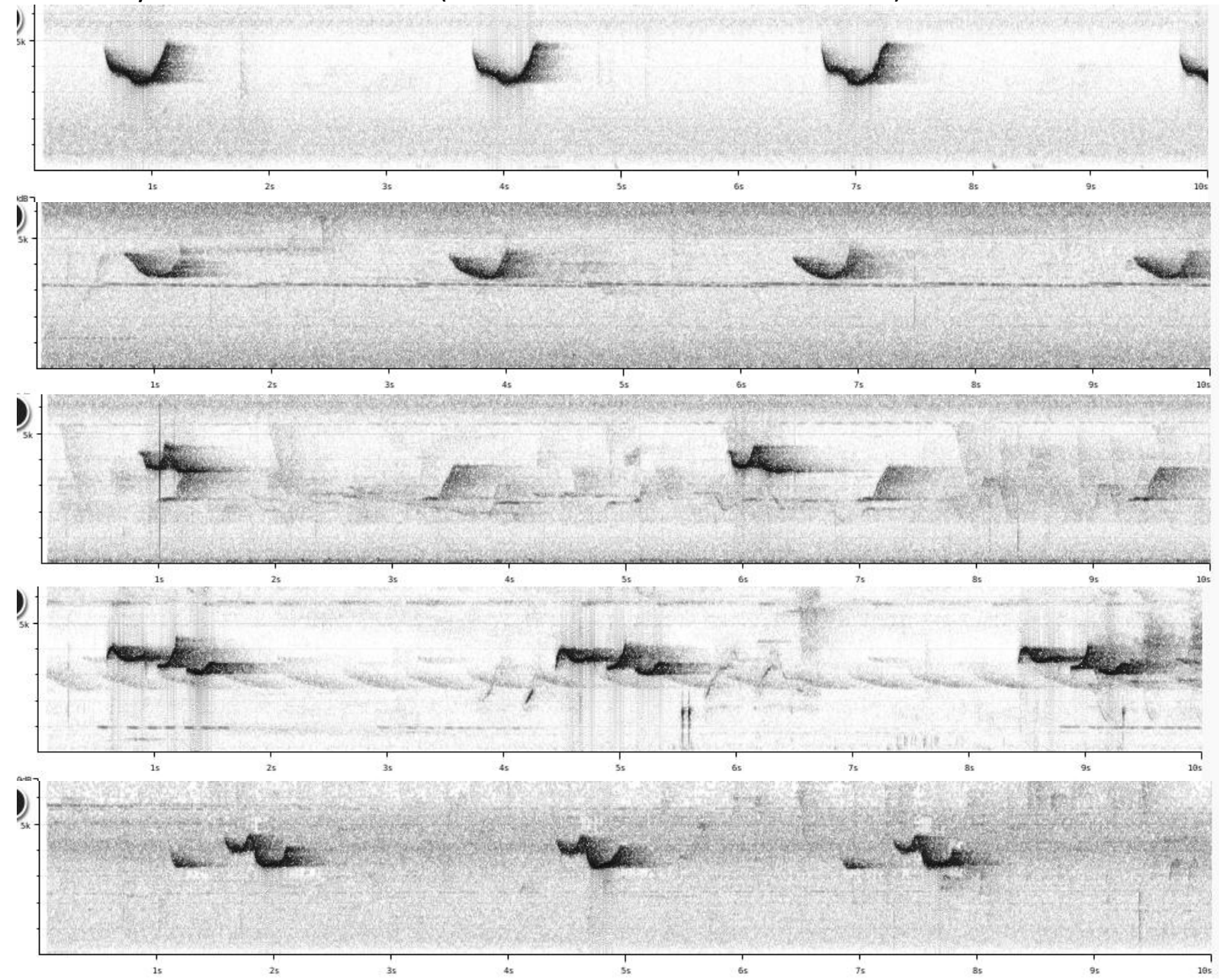

capistratum: whistles are similar in shape to Bornean birds but slightly lower-pitched, typically lowest freq. of most notes lower than or equal to $3 \mathrm{kHz}$, and max. freq. typically below $4 \mathrm{kHz}$ (unlike previous two groups).
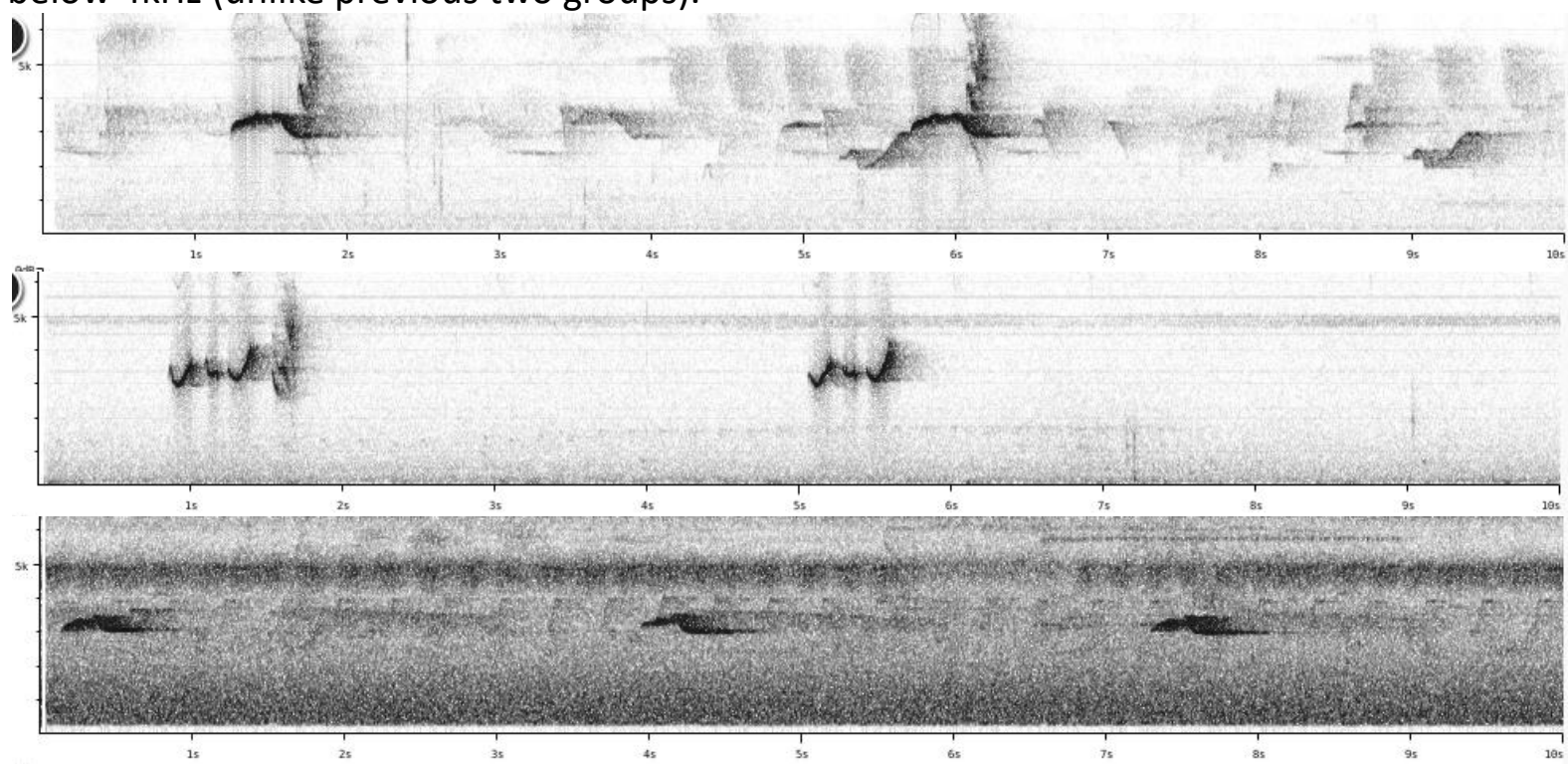
All in all, vocal differences are rather minor, but blind recordings can be attributed to one of the three groups with reasonable certainty in most cases. Quantification of vocal differences would lead to estimated total vocal scores of about 2.

This note was finalized on 12th April 2016, using sound recordings available on-line at that moment. We would like to thank in particular the many sound recordists who placed their recordings for this species on XC.

\section{References}

Tobias, J.A., Seddon, N., Spottiswoode, C.N., Pilgrim, J.D., Fishpool, L.D.C. \& Collar, N.J. (2010). Quantitative criteria for species delimitation. Ibis 152(4): 724-746.

\section{Recommended citation}

Boesman, P. (2016). Notes on the vocalizations of Black-capped Babbler (Pellorneum capistratum). HBW Alive Ornithological Note 269. In: Handbook of the Birds of the World Alive. Lynx Edicions, Barcelona. (retrieved from http://www.hbw.com/node/1251710 on 5 October 2016). 